\title{
THE IMPACT OF ANTICIPATED AND UNANTICIPATED EXCHANGE RATE VARIABILITY IN UKRAINE
}

\author{
Viktor Shevchuk \\ Lviv University of Trade and Economics \\ Email: shevch@lac.lviv.ua
}

\begin{abstract}
This article studies the impact of the anticipated and unanticipated components of the nominal effective exchange rate on Ukraine's main macroeconomic indicators. The study uses quarterly data from 1999 to 2016 and considers the relationship with the budget balance, incomes of trading partner countries, global interest rates, and global raw material prices. Using the time-varying coefficient model (the Kalman filter), the research shows that a depreciation of the hryvnia accelerates wholesale price inflation and negatively affects the performance of GDP and industrial output - these effects were clearly visible after the financial crisis of 2008-2009). However, the research found that only unanticipated changes in the exchange rate have an impact on agricultural production. The results are justified by means of a modified AD-AS model with rational expectations that accounts for the main mechanisms of the influence of the exchange rate on aggregate demand and supply amid a high level of dollarization in the economy.
\end{abstract}

\section{JEL Codes: E31, E51, F37, F41}

Keywords: exchange rate, income, wholesale price inflation, Kalman filter, Ukraine

\section{INTRODUCTION}

In an inflation targeting regime, analyzing anticipated and unanticipated changes to an exchange rate is important for assessing the signal effect from foreign exchange (FX) interventions, which are justifiably viewed as an essential element of the National Bank of Ukraine's (NBU) policy (Grui and Lepushynskyi, 2016). The macroeconomic consequences of a signaled change in an exchange rate may depend on agents' perception of whether disturbances are permanent (anticipated) or temporary (unanticipated). The nature of those expectations is especially significant under conditions of a stabilization policy in economies that lack FX risk hedging tools. Using Mexico as an example, Mendoza and Uribe (2000) show that depreciation expectations can lead to difficulties related to an increase in the interest rate premium, which reduces demand for money, savings, investment, and labor supply. Sanchez (2005) provides theoretical proof that fear of a floating exchange rate can be explained by the central bank raising interest rates in response to the restrictive effect of currency depreciation, which is accompanied by an acceleration of inflation. This only serves to worsen the decline in output and provokes criticism against anti-inflation monetary policy.

Although cases of reduced incomes seem to be more a product of currency depreciation than an anti-inflation interest rate increase (Frankel, 2005), the depreciation shock as the main reason for a drop in output is often explained by pre-crisis imbalances - especially in the case of an FX crisis. Therefore, depreciation actually has a stimulus effect when taking the circumstances into consideration (Bussière et al., 2012). This approach has been and remains popular in Ukraine. For example, the economic recovery of 1999-2000 was related to a substantial depreciation of the hryvnia (Stelmakh, 2001), while any measures to strengthen the currency were considered harmful. The idea of a clear benefit from an undervalued exchange rate and being doomed to a weak hryvnia still has its proponents in the current post-crisis economic environment - against the backdrop of a sharp depreciation from UAH 8/USD to UAH 26-27/USD. For example, Yurchyshyn (2016) believes the administrative measures to restrain a further depreciation of the hryvnia adversely affected the manufacturing sector and the household's welfare, accelerated the economy's dollarization, and provoked greater panic among the public.

This article aims to assess the impact of anticipated and unanticipated changes to the nominal effective exchange rate (NEER) upon the main macroeconomic indicators of the Ukrainian economy: GDP, industrial and agricultural production growth, and 
wholesale price inflation. The empirical estimates utilize the time-varying coefficient model (Kalman filter), which accounts for possible structural changes and complies overall with the concept of rational expectations. The author's own modification of the standard AD-AS model is used to provide theoretically consistent explanations for the functional relationships. The theoretical analysis offers a better understanding of the exchange rate impact, while the empirical results are important in assessing the effectiveness of FX interventions as an auxiliary element of inflation targeting policy.

The article starts by providing an overview of the main studies on the topic of the macroeconomic effects of the exchange rate. The paper then outlines the potential differences between the consequences of anticipated and unanticipated changes in the exchange rate (using the standard AD-AS model with rational expectations), describes the source data and the research method, and explains the findings. The final section provides concise conclusions and recommendations to summarize the study.

\section{LITERATURE REVIEW}

In the model, which accounts for aggregate demand and supply mechanisms, Agenor (1991) showed that an anticipated devaluation under a fixed exchange rate regime had a negative effect on income, while unanticipated devaluation is of a favorable impact. That marks a difference from the earlier models of the 1970s and 1980s, which found that the effect of an anticipated change in the exchange rate depended on the relative strength of the mainly expansionary factors of aggregate demand and the restrictive factors of aggregate supply. Agenor's conclusions had been empirically supported using data from 23 developing countries.

Kandil and Mirzaie (2003) proposed a modified AD-AS model, in which unanticipated devaluation increases aggregate demand through improvements in the trade balance, but it also increases demand for money thus restricting the supply of goods and services at the expense of higher import prices. Since unanticipated depreciation leads to a favorable price "surprise" (prices rise by more than expected), there is higher demand for labor, which translates into an increase in wages. Consequently, the employment level and output also rise. The impact of a devaluation on the aggregate supply depends on which effect prevails: whether it is an expansionary price "surprise" factor or a restrictive factor of higher prices for imported raw materials. For 33 developing countries, research shows that an unanticipated increase of the real exchange rate (RER) has a restrictive effect in two countries and an expansionary effect in three countries only. In the remaining countries, the regression coefficients were not statistically different from zero. Consumer prices grew in four countries and fell in two countries. The impact of the anticipated component of the RER on income levels and prices was not determined (except in one country that experienced price hikes).

Later, Kandil (2015) found that in Latin American countries, a devaluation - both anticipated and unanticipated - tends to have a restrictive effect and accelerate inflation (unpredictable changes in an exchange rate are stronger in a system of floating exchange rates). As for Australia, Kohler et al. (2014) found that an unanticipated decrease of the RER by 10\% prompts GDP to temporarily increase by $0.25-0.5 \mathrm{pp}$ over two years and to increase permanently by $1 \mathrm{pp}$ over three years (with inflation growing $0.25-0.5 \mathrm{pp})$.

Additional theoretical arguments stem from the distribution of demand for and supply of goods of domestic and foreign trade $-Q^{N}$ and $Q^{\top}$, respectively (Lizondo and Montiel, 1988). Price increases for imports becomes restrictive if the size of the wage increase is lower than the currency devaluation. Since the impact of an anticipated devaluation on the RER is lower than in the case of an unanticipated change in the exchange rate, the macroeconomic effects should also be lower. An increase in the costs of working capital due to an increase in interest rates is practically the only factor that restricts the supply of goods QT directly because of devaluation. This mechanism used to be called the "Cavallo effect".

Leaving aside the decomposition into the anticipated and unanticipated components, empirical studies mostly find a standard expansionary effect from a devaluation in industrial countries, mainly due to increased exports and reduced imports, while restrictive effects prevail in developing countries (Bahmani-Oskooee and Miteza, 2006; Hutchison and Noy, 2002). At the same time, a decline in production is seen, both in the case of a devaluation under a fixed exchange rate and depreciation under a floating exchange rate (Ahmed et al., 2002). Restrictive devaluation is found to prevail in Latin American countries (Bebczuk et al., 2006; Pineres and Cantavella-Jorda, 2010), but it is also not uncommon in Asian countries either (Chou and Chao 2001; Moreno, 1999). Since an improvement in the trade balance is combined with a decline in the government revenues in Latin American countries (An et al., 2014), the aggregate supply is concluded to be the dominant factor.

Earlier studies on the Central and Eastern European (CEE) countries mainly showed a restrictive devaluation effect (Miteza, 2006), while later studies demonstrated rather ambiguous results across different countries (Bahmani-Oskooee and Kutan, 2008). The results are more favorable for excgange rate depreciation effects when using the RER (Mirdala, 2013), which can be interpreted in favor of a 'weaker' currency. However, in a number of studies, the strengthening of the RER is a factor behind an increase in output in Bulgaria (Hsing and Krenn, 2016), Slovakia (Hsing, 2016a), the Czech Republic (Hsing, 2016b), and Croatia (Hsing, 2016c). In Macedonia, a weakening of the exchange rate drives up inflation but does not affect output (Fetai and Zeqiri, 2010). Poland is practically the only country where empirical studies have shown a sustained expansionary effect from an exchange rate depreciation (Haug et al., 2013; Twarowska, 2015; Mills and Pentecost, 2001). 
Notably, an expansionary effect from a declining RER does not mean that a currency devaluation will produce a similar effect, as it may be hindered by a pass-through effect in domestic prices. Freund and Pierola (2012) found that a moderate decline in the RER (by 20\%) creates a favorable precondition for an increase in exports of industrial goods, as long as the nominal exchange rate remains stable. However, in the CEE countries, research shows that each percent of devaluation increases the RER by $0.5 \%$ to $0.6 \%$, while the pass-through effect is slightly higher for countries with a fixed exchange rate (Beirne and Bijsterbosch, 2009).

Particular difficulties for an analysis of exchange rate effects used to be found in the case of large devaluations of a currency (by more than 20\%) resulted from the currency crisis. Based on a study of 195 currency crises in 91 developing countries from 1970 to 1998, IMF experts found that both expansionary and restrictive effects can be obtained (with a higher probability of the latter in large and more developed economies, with a significant inflow of capital on the eve of the currency crisis) (Gupta et al., 2003). Efforts to restore production levels are hampered by policies aimed at curbing the money supply, which are coupled with an increase in the budget deficit. However, a more recent study for 108 developing countries over 1960 to 2006 is more categorical: currency crises serve to restore GDP growth, which was slowed by destructive pre-crisis factors (Bussière et al., 2012). At the same time, no any impact of currency crises on the macroeconomic effects of the exchange rate has been found for the Southeast Asia countries (Moreno, 1999).

In addition to the above mentioned context of the crisis or "normal" conditions, the varied impact of the exchange rate can also be attributed to heterogeneous factors such as the business cycle, the specifics of capital flows, economic dollarization, openness to foreign trade, critical overstatement of the RER, and related external conditions (Bebczuk et al., 2006; Bussière et al., 2012). The mechanisms of a restrictive exchange rate impact are no less diverse: low price elasticity of exports and imports, wage cuts, capital flight (Kamin and Rogers, 2000; Lizondo and Montiel, 1988), redistribution of income in favor of richer strata of the population with a higher propensity for saving, improvements in the budget balance because of higher tax revenues from exporter companies (Krugman and Taylor, 1978), a decrease in the value of financial assets of local companies (Delli Gatti et al., 2007), the balance effect when the post-devaluation costs of external debt servicing increase significantly (Blanchard et al., 2010). The Marshall Lerner Condition used to be held in modern economies, mainly due to the high import price elasticity (IMF, 2006). In general, devaluation can be both expansionary and restrictive. However, in large economies, the effect of relative prices prevails in foreign trade (exports grow and imports decrease), while in small economies - imports fall due to lower incomes (Acevedo et al., 2015).

The probability of a restrictive exchange rate effect is enhanced by:

a) a high proportion of imported goods in the determination of the overall price level;

b) inflationary pass-through;

c) the predominance of money supply in the total value of private sector assets.

Recently, a weaker pass-through effect to inflation can be explained in various ways (a decrease in the long-term inflation rate, a change in the export-import structure), but the most relevant explanation is based on the liberalization of trade (lower duties), the reduction of transport costs, and the cost of labor-intensive wholesale and retail services (Frankel, 2005). However, this may not be applicable to economies that are used to prices in the dollar equivalent. On the aggregate supply side, the dependence of output on imported components and the increase of capital value in economies with capital-intensive technologies exerts a negative effect (Forbes, 2002).

Although many studies reject the largely restrictive effect of currency devaluations, primarily over the long run, and relate heterogeneity of exchange rate effects to differences per capita income (e.g., Kamin and Klau, (1998)), most papers suggest just the opposite. At the same time, it is true that the macroeconomic impact of the exchange rate differs in different countries and depends on many mechanisms that work in opposite directions. Another problem stems from a possible instability of the functional relationships over time. The empirical studies for Ukraine based on pre-crisis data showed an expansionary effect on industrial output from the depreciation of the RER, but a restrictive effect from the depreciation of the hryvnia exchange rate against the US dollar. Post-crisis empirical estimates show a stimulating effect on industrial production growth, but a simultaneous deterioration of the agricultural production growth (Shevchuk, 2016a). If we use estimates with flexible coefficients and account for the effect of the currency crisis using corresponding dummy variables, the depreciation of the hryvnia improved the industrial production trend up to 2009; after 2014 a weak restraining effect is observed. A reduction of imports is mainly responsible for the improvement in the trade balance. However, the direct effect of a currency crisis is restrictive for industrial production, as well as for export and import volumes.

\section{THEORETICAL MODEL}

This study uses the AD-AS model with rational expectations to illustrate the main influence mechanisms of anticipated and unanticipated changes in the exchange rate ${ }^{1}$ :

${ }^{1}$ The chosen variant of the AD-AS model takes into account most important functional relationships of aggregate supply and demand as it is elaborated in several studies (Agenor, 1991; Kandil and Mirzaie, 2003; McCallum, 1996; Rojas-Suarez, 1992). The main novelty is accounting for the dollarization of the money supply and for the exchange rate surprise of the aggregate supply. 


$$
\begin{aligned}
& y=a_{1}\left(m_{t}-E_{t-1} p_{t}\right)-a_{2} E_{t-1}\left(e_{t}+p_{t}^{*}-p_{t}\right)-a_{3}\left(e_{t}-E_{t-1} e_{t}\right)+u_{t}, \\
& y=b_{1}\left(m_{t}-E_{t} i_{t+1}\right)+b_{2} E_{t}\left(e_{t+1}+p_{t+1}^{*}-p_{t+1}\right)-b_{3} r_{t}+b_{4} g_{t}+b_{5} y_{t}^{*}+v_{t}, \\
& m_{t}=\varphi h_{t}+(1-\varphi)\left(e_{t}+f_{t-1}\right) \\
& i_{t}=\gamma p_{t}+(1-\gamma)\left(e_{t}+p_{t}^{*}\right) \\
& r_{t}=r_{t}^{*}+E_{t} e_{t+1}-e_{t}-\left(E_{t} i_{t+1}-i_{t}\right), \\
& e_{t}=\rho e_{t-1}+\varepsilon_{t},
\end{aligned}
$$

where $y_{\mathrm{t}}$ and $y_{\mathrm{t}}^{*}, p_{\mathrm{t}}$ and $p_{\mathrm{t}}^{*}, r_{\mathrm{t}}$ and $r_{\mathrm{t}}^{*}$ respectively represent GDP (income), domestic prices, and the real interest rate in the domestic country and abroad; $m_{t}$ is the aggregate money supply; $h_{t}$ is the internal component of the money supply; $f_{t}$ is FX assets; $e_{t}$ is the exchange rate (the value of foreign currency defined in the domestic currency), $\varepsilon_{t}$ is the unanticipated exchange rate component; $i_{t}$ is the general price level; $u_{t}$ and $v_{t}$ are stochastic aggregate supply and demand shocks, respectively. Except for $r$ and $r^{*}$, all series are in logarithms. $E_{t}$ and $E_{t-1}$ imply the expectation operators formed at the beginning of periods $t$ and $t-1$, respectively.

Model (1)-(6) outlines the main impact mechanisms of the exchange rate to be of interest. Equations (1) and (2) define the factors of aggregate supply and demand, respectively. The central bank controls only a part of money supply $h_{t}$ (equation (3)), while the rest are FX assets of the private sector $f_{t-1}$ (in domestic currency, with the exchange rate taken into account). The overall price level includes both domestic and imported goods and services, while coefficient 1- $\gamma$ can be viewed as a measure of the pass-through effect (equation (4)). The real interest rate depends on the world interest rate as well as expectations of exchange rate depreciation and inflation (equation (5)). Finally, two components of equation (6) - anticipated $\rho e_{t-1}$ and unanticipated $\varepsilon_{t}$ - determine the exchange rate. If the exchange rate changes are unanticipated (temporary), $\rho=0$; if they are completely anticipated (permanent), $\rho=1$.

Our specification of the aggregate supply corresponds to the microeconomic explanation of the production function for a dollarized economy with financial constraints (Rojas-Suarez, 1992), but takes into account the possible currency surprise (Sanchez, 2005). The inverse relationship between the aggregate supply and the exchange rate makes it similar to the model of Agenor (1991), although it does not limit the price surprise to domestic price expectations (like the Friedman-Phelps hypothesis).

Output depend on real lending (financial effect $a_{1}$ ) and a stochastic shock $u_{t^{\prime}}$ whereas a depreciation of the real exchange rate (RER) (price effect $a_{2}$ ) and the exchange rate surprise $\left(a_{3}\right)$ have an opposite restrictive effect (equation (1)). Businesses make decisions on the production of goods and services based on expectations formed at the beginning of the current period. Therefore, in the current period, the impact of an anticipated hryvnia depreciation is materialized only through an increase in the value of financial assets $\mathrm{f}_{\mathrm{t}-1}$ (in the domestic currency) and the exchange rate surprise. A depreciation of the hryvnia above its expected value $\left(e_{t}>E_{t-1} e_{t}\right)$ hampers output growth due to higher cost of short-term lending to meet current production needs, or for several other reasons. For example, an excessive depreciation may be seen as a sign of further difficulties in the manufacturing sector or may increase incentives for FX savings, which are unrelated to current production activity.

Equation (2) relates the aggregate demand to money supply (the wealth effect $b_{1}$ ), RER expectations (the price effect $b_{2}$ ), the real interest rate, government spending, foreign income, and stochastic shocks. This specification corresponds to the specification of aggregate demand by Agenor (1991), but takes into account the dependence of demand on the interest rate as in the IS-LM framework, in line with proposals by Kandil and Mirzaie (2003). The respective relationships for the specification with rational expectations can be found in the studies of Rojas-Suarez (1992) or McCallum (1996). The wealth effect is limited to monetary assets, although, in general, it can also account for the value of real estate, securities, etc. Depreciation can stimulate demand by improving relative prices in foreign trade and reducing the real interest rate. The wealth effect has a stimulating impact in a dollarized economy (low value of $\varphi$ ) with a weak dependence of the general price level on imports (high value of $\gamma$ ). The stochastic shock $v_{t}$ can be viewed as a sign of greater preference for current consumption.

The formal solution of the equation system (1)-(6) for income and domestic prices is as follows:

$$
\begin{aligned}
& y=\bar{y}+(1 / \Delta)\left\{\left[\left(b_{2}-(1-\gamma) b_{1}\right) a_{1}+a_{2} b_{2}\right]\left(\varphi h_{t}+(1-\varphi) f_{t-1}\right)+\right. \\
& \left.+\left[\left((1-\gamma) b_{1}-b_{2}\right) a_{1}-a_{2} b_{1}\right] p_{t}^{*}+\left(a_{2}-a_{1}\right)\left(b_{4} g_{t}+b_{5} y_{t}^{*}-b_{3} r_{t}^{*}\right)\right\}- \\
& -\left(1 / \Delta_{1}\right)\left[\rho a_{1}\left((1-(1-\varphi) \rho) b_{2}-\varphi(1-\gamma) b_{1}-(1-\varphi)(1-\rho) \gamma b_{3}\right)+\right. \\
& \left.\left.\left.+a_{2}((\gamma+(\varphi-\gamma) \rho)) b_{1}+(1-\rho) \gamma b_{3}\right)-(1-\rho) a_{3}\left(\gamma b_{1}+\rho b_{2}+(1-\rho) \gamma b_{3}\right)\right)\right] e_{t-1} \\
& +\left[\left((1-\varphi) a_{1}-a_{3}\right)\right] \varepsilon_{t}+u_{t},
\end{aligned}
$$




$$
\begin{aligned}
& p=\vec{p}+(1 / \Delta)\left\{\left(b_{1}-a_{1}\right)\left(\varphi h_{t}+(1-\varphi) f_{t-1}\right)+\left[a_{2}+b_{2}-(1-\gamma) b_{1}\right] p_{t}^{*}+\right. \\
& \left.+b_{4} g_{t}+b_{5} y_{t}^{*}-b_{3} r_{t}^{*}\right\}+\left(1 / \Delta_{1}\right)\left[a_{2}+\rho b_{2}-\rho(\varphi-\gamma) b_{1}-(1-\varphi) \rho a_{1}-(1-\rho) a_{3}\right] e_{t-1} \\
& +\left(1 / \Delta_{2}\right)\left[\left(b_{2}-\gamma b_{3}\right) \frac{a_{2}+\rho b_{2}-\rho(\varphi-\gamma) b_{1}-(1-\varphi) \rho a_{1}-(1-\rho) a_{3}}{\Delta_{1}}-\right. \\
& \left.-(1-\varphi) a_{1}+a_{3}+\gamma b_{3}+(\varphi-\gamma) b_{1}\right] \varepsilon_{t}+\left(1 / \Delta_{2}\right)\left(v_{t}-u_{t}\right),
\end{aligned}
$$

where $\bar{y}$ and $\bar{p}$ are the equilibrium values of income and domestic prices, respectively

$$
\begin{aligned}
& \Delta=\gamma b_{1}+b_{2}+a_{2}-a_{1}, \\
& \Delta_{1}=\gamma b_{1}+(1-\rho) \gamma b_{3}+\rho b_{2}+a_{2}-a_{1}, \\
& \Delta_{2}=\gamma b_{1}+\gamma b_{3} .
\end{aligned}
$$

An unanticipated depreciation has an expansionary effect on income through the financial effect $a_{1}$. At the same time, there is a negative impact of an increase in the costs of working capital. It is clear that the impact of $\varepsilon_{t}$ becomes restrictive if there is no dollarization $(\phi=1)$. The impact of unanticipated depreciation on domestic prices is complex and depends on the structural features of an economy. Anticipated depreciation would most likely have a restrictive effect and would drive prices upwards (obviously, these relationships become unambiguous if $\rho=1$ and $\gamma=1$ ). In any case, the impact of the exchange rate on income and domestic prices is intricate, and it is further complicated by the dollarization of the economy.

Interpretation of other independent factors is simpler. The money supply stimulates income if the price effect exceeds the welfare effect $\left(b_{2}>b_{1}\right)$; the less prices depend on imports, the better. At the same time, both the structural features have no impact on the link between money supply and domestic prices, which is determined by the relative strength of financial and wealth effects. If these effects are equal $\left(a_{1}=b_{1}\right)$ and the same condition does hold for the respective price effects $\left(a_{2}=b_{2}\right)$, the impact of money supply becomes clearly restrictive.

The strong price effect prompts a decline in income and growth in domestic prices in response to a global price hike. If the financial effect is weaker than the price effect $\left(a_{1}>a_{2}\right)$, one can expect that the intuitively expected growth in income will materialize as a result of higher government spending and income of trading partner countries, as well as due to a decline in the world interest rate. In all three cases, the expansionary effect is accompanied by a rise in domestic prices. A stochastic aggregate supply shock $\left(u_{t}>0\right)$ is expansionary and has an anti-inflation effect, whereas a shock on the side of aggregate demand $\left(v_{t}>0\right)$ has no influence on effect on income and drives domestic prices upwards.

\section{SOURCE DATA AND STATISTICAL METHOD}

The empirical estimates used quarterly data for 1999-2016 from the databases of the State Statistics Service of Ukraine (www.ukrstat.gov.ua) and the IMF's International Financial Statistics (www.imf.org). The research is focused on the relationship between GDP $\left(y_{t}\right)$, as well as industrial and agricultural production as its individual components (index, 1999=100), and wholesale prices $\left(p_{t}\right)$ and a number of independent variables as envisaged in model (1)-(6). The approximate value of FX assets ( $\mathrm{ft}$ ) is proxied with the indicator of FX deposits in the banking system (in million US dollars). Such a choice is not perfect (FX deposits may be negatively correlated with assets outside banks, for example during crises), but other data on the FX assets of private Ukrainian individuals and companies is not available. The domestic component of the money supply $\left(h_{t}\right)$ was obtained by subtracting the value of FX bank deposits from the monetary aggregate $\mathrm{M} 2$ (expressed in million hryvnias). The budget balance (\% of GDP) was taken as the approximate value of net government spending $\left(g_{t}\right)$, the LIBOR rate as the world global interest rate $\left(r_{t}^{*}\right)$, and as income of trading partner countries $\left(y_{t}^{*}\right)$ we used industrial production in the euro area (indeuro ${ }_{t}$ ) and both GDP and industrial production in Russia ( $y r u s_{t}$ and indrus ${ }_{t}$ respectively). Dependent on the specification of the statistical model, world prices $\left(p_{t}^{*}\right)$ are proxied with commodity price indexes for metal (metal $\left.{ }_{t}\right)$, crude oil $\left(b r e n t_{t}\right)$, and agricultural raw materials $\left(\right.$ praw $\left._{t}\right)$.

Indicators of GDP, industrial and agricultural production (in real terms), and money supply components were seasonally adjusted using the Census X-11 method. All variables were used in logarithms, except LIBOR and the budget balance. 
The Beveridge-Nelson decomposition (Beveridge and Nelson, 1981) was applied to extract permanent (anticipated) and temporary (unanticipated) components of the nominal effective exchange rate (index, 2010=100):

$$
\varphi(L)\left[\Delta e_{t}-\eta\right]=\theta(L) \xi_{t}
$$

where the permanent (anticipated) component is equal to:

$$
\Delta e_{t}=\eta+\psi(1) \xi_{t}, \quad \psi(L)=\theta(L) \varphi(L)^{-1},
$$

and the temporary (unanticipated) component is defined as:

$$
\varepsilon_{t}=\tilde{\psi}(L) \xi_{t}, \quad \tilde{\psi}(L)=-\sum_{k=j+1}^{\infty} \psi_{k} .
$$

Essentially, it is about dragging of the current NEER values through the autoregressive filter. The NEER behavior is found to be compliant with the ARIMA process $(3,1,2)$. In-sample one-step ahead forecasts constitute the permanent (anticipated) components for the NEER, while the respective forecast errors constitute the temporary (unanticipated) parts of the NEER. Such an interpretation of the Beveridge-Nelson decomposition seems to be relevant for the logic of the model with rational expectations, while not without being open to criticism. ${ }^{2}$

Figure 1 shows the results of the NEER decomposition into the anticipated and unanticipated components. The trajectory of the permanent (anticipated) NEER component is quite predictable: a lasting period of currency stability follows every sudden crisis-driven transition to a much lower value. A slight anticipated strengthening of the NEER was observed only in 2002-2004 and 2011-2013. The most unexpected development was the depreciation of the hryvnia in 2015-2016. Surprisingly, the fall of the exchange rate in 2014 seems rather predictable. The hryvnia depreciation of 2008-2009 did not surprise the market. At the same time, 1999, 2002, and 2010 were full of exchange rate surprises. The NEER strengthened unpredictably in 2003 and 2011. Notably, the two official hryvnia revaluations (April 2005 and May 2008) do not seem unanticipated.

\section{Figure 1. NEER decomposition using the Beveridge-Nelson method (in logarithms, 2010=100), 1999-2016}

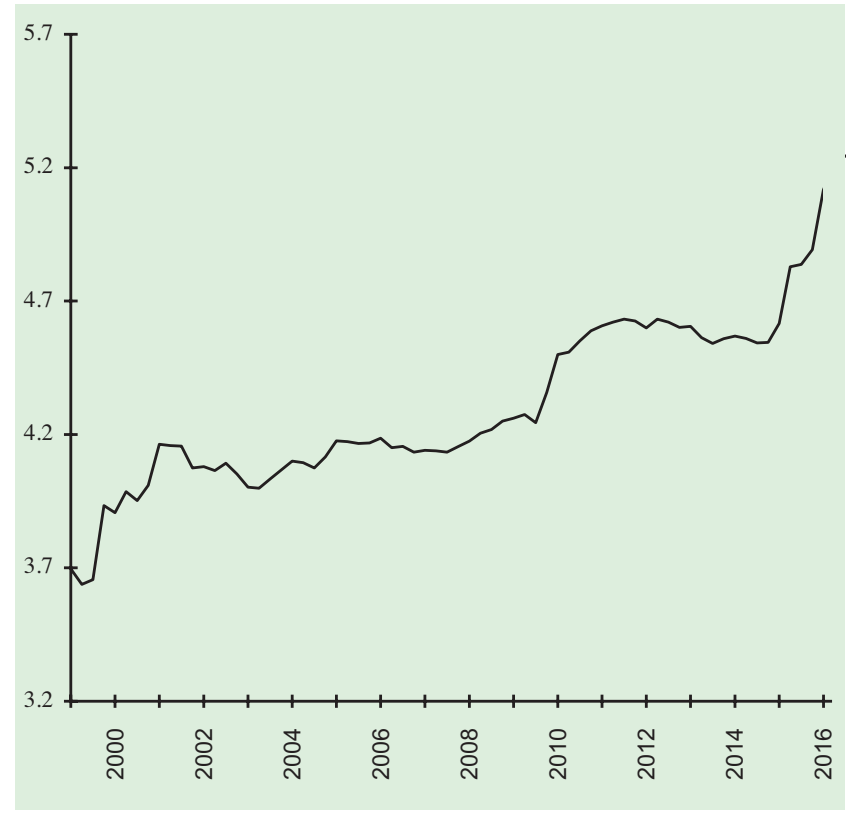

a) Permanent (anticipated) component

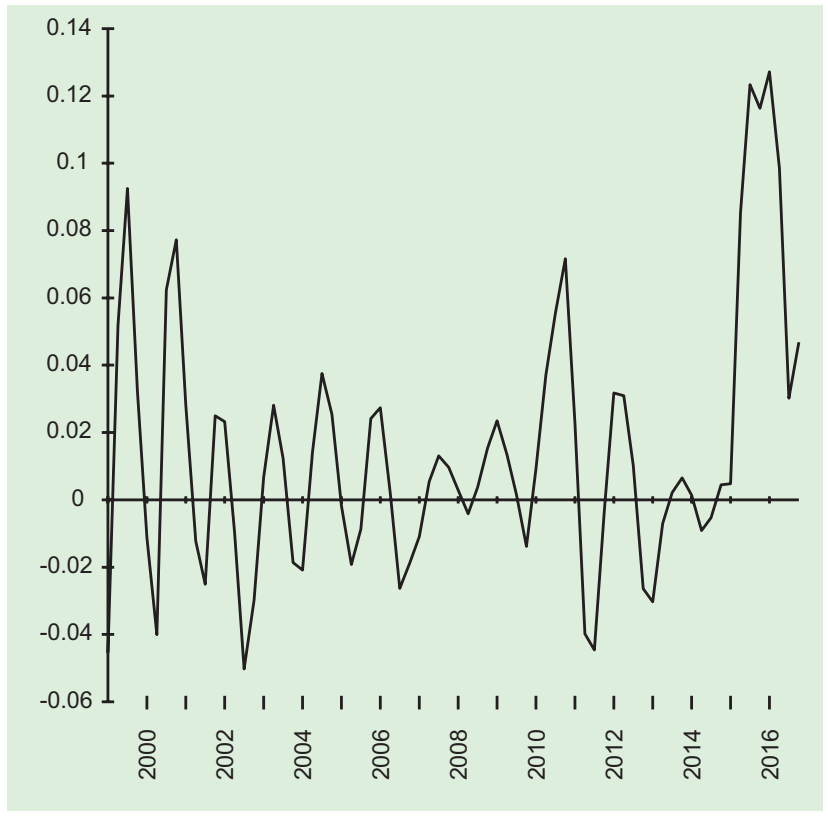

b) Temporary (unanticipated) component

Source: Author's estimates according to the IMF International Financial Statistics data.

\footnotetext{
${ }^{2}$ As explained by Morley (2011, pp. 419-439), the Beveridge-Nelson decomposition is subject to two very distinct interpretations. One interpretation is such that the optimal long-run forecast (minus any deterministic drift) corresponds to an estimate of an unobserved permanent component, while the alternative interpretation is that the optimal long-run forecast defines an observable permanent component. It is demonstrated that both interpretations are empirically distinguishable in a multivariate setting, but it is not the case in a univariate setting. Contrary to quite a popular view that the Beveridge-Nelson decomposition defines trend, on the basis of U.S. macroeconomic data it is found support for interpreting the Beveridge-Nelson decomposition as indeed providing estimates of trend and cycle.
} 
The choice of the NEER as exchange rate variable is convenient from both a technical and a methodological point of view. First, the NEER indicator is sufficiently volatile while retaining a high correlation with the UAH/USD exchange rate (0.94). Second, a substantial share of Ukraine's export and import operations are conducted in euro, which provides the necessary unpredictability to the behavior of the exchange rate. Third, maintaining the fixed UAH/USD exchange rate de facto does not mean that there are no exchange rate expectations that are significantly different from the value of informal currency peg parity. Forming exchange rate expectations based on the money supply may be one of the explanations (Rojas-Suarez, 1992; Shevchuk, 2008). In this case, the nominal exchange rate may remain unchanged but expectations will change depending on the monetary policy stance. However, this study does not cover that possibility; it remains a subject for future research.

The statistical model with time-varying coefficients (TVP) comprises two equations:

$$
\begin{aligned}
& x_{t}=\beta_{1, i} \text { neera }_{t-1}+\beta_{2, t} \text { neers }_{t}+\beta_{3, t} \mathbf{K}_{t}+\xi_{t}, \\
& \beta_{j, t}=\beta_{j, t-1}+\zeta_{j, t}, \quad j=1,2,3,
\end{aligned}
$$

where $x_{t}$ is a dependent variable, neera $a_{t}$ and neers are the anticipated and unanticipated NEER components, $\mathbf{K}_{t}$ is the vector of independent variables, and $\xi_{t}$ is the stochastic factor.

Equations (12) and (12a) show the functional structure of the statistical model and the nature of the time-varying coefficients, respectively. Stochastic factors $\xi_{t}$ and $\zeta_{t}$ are assumed to have a normal distribution and not to be correlated with each other. Practically all the time-varying coefficients are modeled as recursive ones $\left(\zeta_{i, t}=0\right)$. However, the neers ${ }_{t}$ coefficients in GDP and industrial output equations turned out to be compliant with the assumption of random walk without drift. In addition, the time-varying coefficients $\beta_{3, t}$ relate to the vector of the independent variables $\mathbf{K}_{\mathbf{t}}$.

The main advantage of the TVP method lies in the possibility to account for the structural instability of functional relations, for example, those caused by an FX crisis. In a wider context, time-varying coefficients allow the model to abstract away from factors such as the business cycle or openness to foreign trade. To control for the critical overvaluation of the RER or the scale of an abrupt exchange rate realignment (moderate or substantial), relevant dummy variables should be used, as in our previous study with the monthly data (Shevchuk, 2016b). As for quarterly data, there is simply not enough historical data available. In addition, the use of the time-varying estimates significantly neutralizes the dependence of the results on the specifications of the statistical model. For example, there were no significant changes in findings for both exchange rate components after taking into consideration variables for external debt and both direct and portfolio investments, which account for the capital flows and thus being responsible for real sector developments.

\section{EMPIRICAL FINDINGS}

The estimates of the GDP dynamic functional relations show a vivid change in the impact of an anticipated decline in the NEER depreciation - from neutral to restrictive stance - in 2008, after the start of the global financial crisis (see Figure 2). ${ }^{3}$ The unanticipated decline in the NEER was neutral up to 2009 and turned expansionary for a short time in the mid-2010, but then a downward trend followed. According to model (1)-(6), the occurrence of the restrictive impact indicates that the adverse exchange rate surprise in the aggregate supply exceeds the favorable financial effect when an unanticipated currency depreciation worsens current business opportunities. The local weakness of this mechanism explains the expansionary effect observed in 2010.

An increase in the domestic component of the money supply has no influence on GDP dynamics. On the other hand, the FX component had a stimulating impact until 2008, but has since become neutral. The improvement in the budget balance showed weak signs of a restrictive impact in 2002-2005, but afterwards the link between the two components disappeared and then a stimulating effect emerged in 2015-2016. A pick-up in industrial production in the euro area is an important factor in the acceleration of GDP growth, although in recent years, its impact has been halved compared to the middle of the previous decade. In 2004-2006, a one percent growth in industrial production in Europe added up to 1.2 pp to Ukraine's GDP growth rate. That effect weakened to 0.4 as at the end of 2016. Curiously, Ukraine's reliance on the Russian GDP emerged only in 2008-2009, but as expected, it has weakened starting in 2014: the time-varying coefficient declined to 0.32 from 0.44 for the respective periods.

\footnotetext{
${ }^{3}$ The time-varying coefficients shown in Figures 2-5 reflect the statistical model's specifications used in each of the cases, i.e., they refer to the list of independent variables. It is worth noting that this list differs for individual dependent variables, and the choice is based on the best statistical properties of the estimated model. For this reason, the world crude oil price index (brent $t_{t}$ ) was not included into the models for the GDP and agricultural production. It is obvious why the indicator for world prices for agricultural raw materials $\left(\right.$ praw $\left._{t}\right)$ is not included into the GDP and industrial production models and why the world metal price index (metal $)_{t}$ is not used in the agricultural production model.
} 
Figure 2. Determinants of GDP dynamics (in first differences)
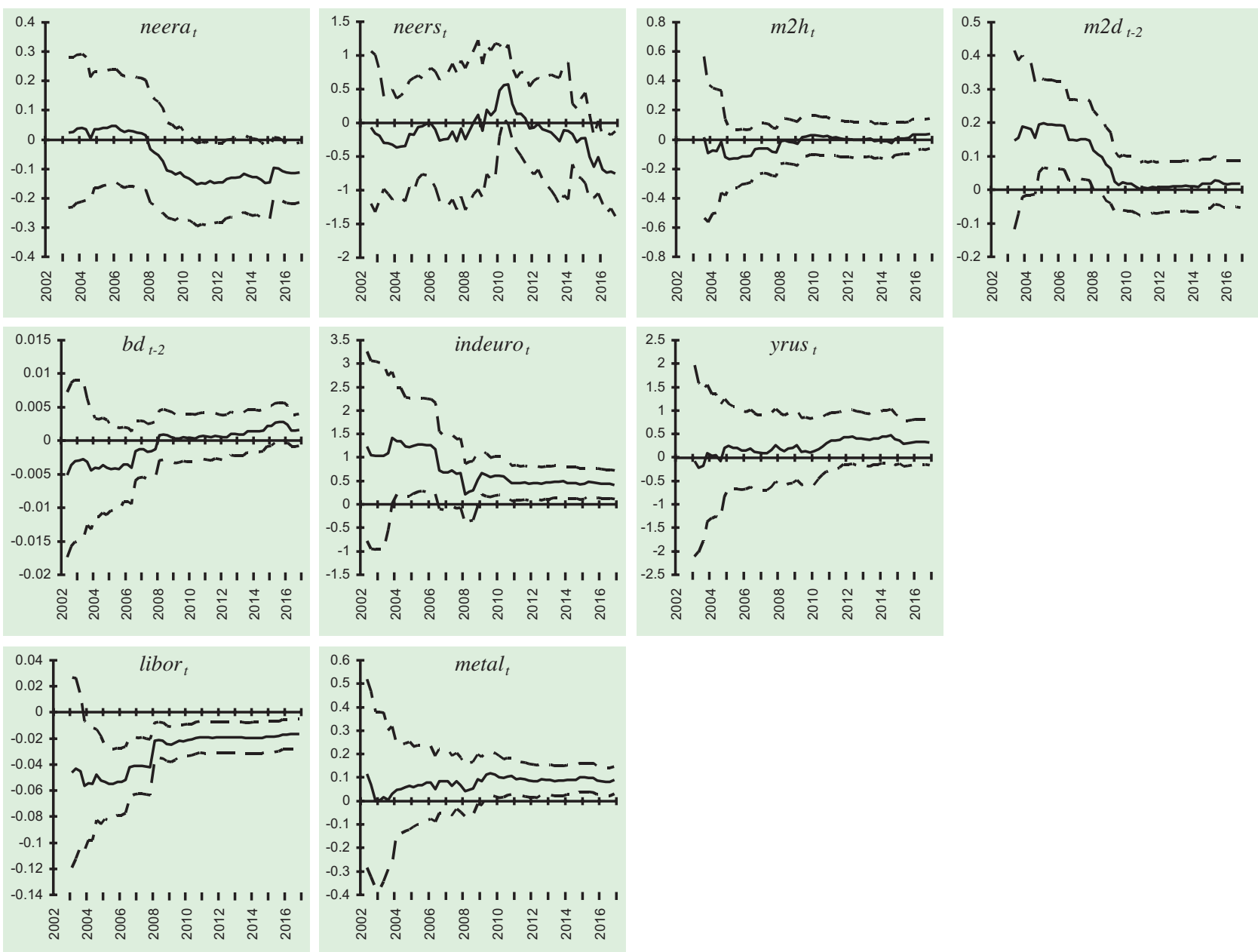

Note: hereinafter the confidence interval for the estimated time-varying coefficients is \pm 2 standard deviations.

An increase in the foreign interest rate has a clear restrictive effect, which is fully compliant with model (1)-(6). An increase in metal prices started stimulating Ukraine's GDP only as late as in 2008, which contradicts one of the popular explanations for the economic growth determinants during the boom years in 2002-2007. There is substantial evidence that industry in Europe was the real driver of the Ukrainian economy over those years. The dependence on world metal prices was quite stable over 2010-2016.

The estimates for industrial production do not rule out that an anticipated NEER depreciation may have a restrictive effect (see Figure 3). The restrictive impact of an unanticipated NEER depreciation was also observed in 2014-2016. As of the end of 2016, the anticipated 1 percent decline in the NEER caused the industrial production growth to slow by 0.17 pp and GDP by $0.11 \mathrm{pp}$. The restrictive effect is much stronger in the case of an unanticipated NEER decline: each percent depreciation in the hryvnia reduces the growth rates of industrial production by $0.5 \mathrm{pp}$ (as of the start of 2014, the coefficient was -0.02) and GDP growth by $0.75 \mathrm{pp}(-0.12)$.

Unlike the estimates for the GDP growth, an increase in the domestic component of the money supply stimulated industrial growth in 2002-2008. Afterwards, this favorable effect disappeared and gave way to a weak restrictive effect since the start of 2014 (each percent increase in $m 2 h_{t}$ reduced the industrial growth rate by $0.05 \mathrm{pp}$ ). On the other hand, an increase in the FX component of the money supply became expansionary in 2014-2016, while previously it had no influence on industrial production (each percent of growth in $m 2 d_{t-1}$ accelerated industrial growth by $0.07 \mathrm{pp}$ ). Clearly, these findings contradict the popular belief that it was an acute money shortage that slowed Ukraine's economic growth. More recently, the budget balance has had practically no effect on industrial production, although an improvement in this indicator had created an expansionary effect in the early 2000 s. 


\section{Figure 3. Determinants of industrial production dynamics (in first differences)}
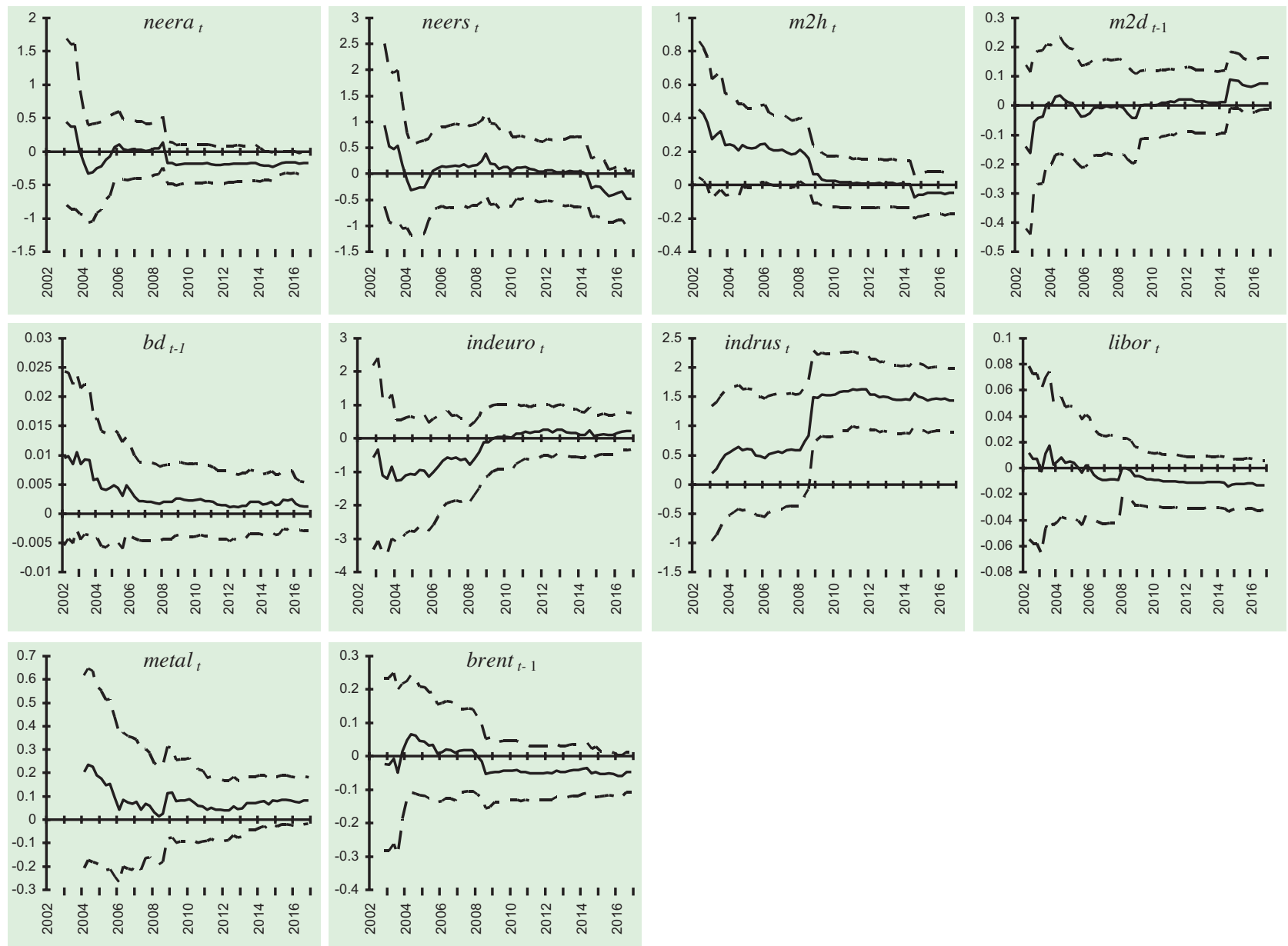

Ukraine's economy still does not depend on industrial production in the euro area, whereas Ukraine's dependence on Russian industrial production remains high despite the recent intense conflict between the two countries (the coefficient on indrus, decreased slightly to 1.43 as of the end of 2016 from 1.54 at the end of 2013). Remarkably, the dependence of Ukraine's economy on Russia more than doubled in 2010-2013. A weak reliance on the world metal prices emerged as late as in 2014-2016. In addition, the inverse relationship with the world crude oil prices strengthened over this period. LIBOR had a negative effect on industrial production, but the respective coefficients lacked statistical significance. That result is not surprising since Ukraine's industrial sector remains more isolated from foreign financial markets than other sectors.

Estimates for agricultural production do not reveal any effects of an anticipated NEER depreciation (see Figure 4). However, the results confirm that an unanticipated decline in the NEER has a restrictive effect, which seems more stable over time (this is partially explained by the use of a recursive model for time-varying coefficients). This effect also became more pronounced in 2014-2016 (the coefficient was -0.6 as of the end of the period). Similar to the estimates for GDP and industrial production, this conclusion provides an extra proof of the importance of the functional relationship between the real sector and exchange rate instability. 
Figure 4. Determinants of agricultural production dynamics (in first differences)
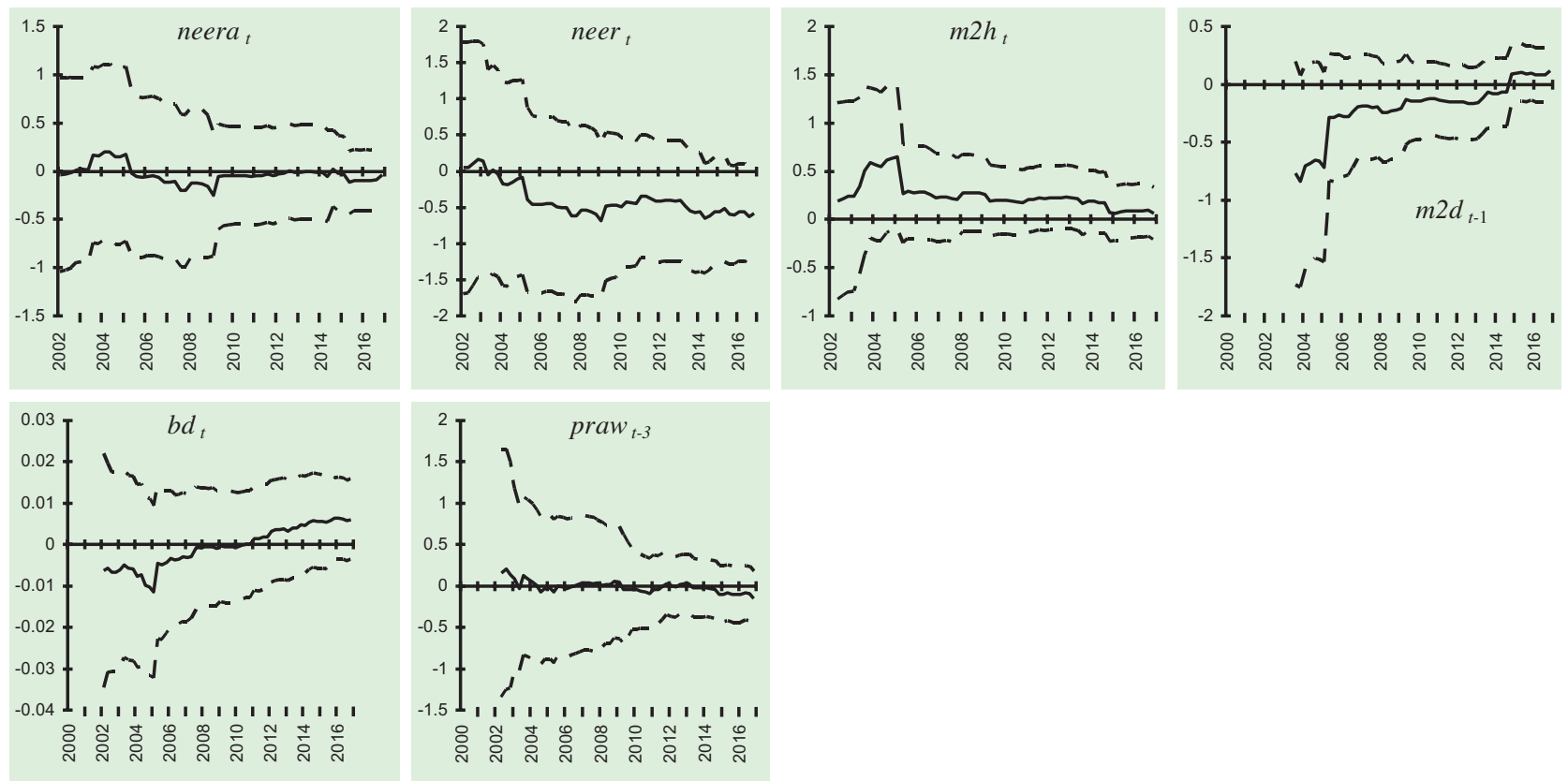

Similar to industry, the agricultural sector benefited from a favorable effect of the domestic component of the money supply in 2002-2005. Afterwards, however, that favourable effect disappeared. The accumulation of FX bank deposits had a negative impact until 2006 and then its effect on agricultural production turned neutral. The budget balance was also neutral for a long time, but its stimulating effect has grown gradually since 2012. The fact that agricultural production did not react to changes in the world agricultural raw material prices seems unusual. There was also no connections to the world crude oil prices.

The findings could mean that unanticipated changes in the exchange rate become stronger if the currency is floating, as found by Kandil (2015). The results also show that both anticipated and unanticipated currency depreciations can be restrictive. This feature marks a difference from results for industrial countries, e.g., Australia (Kohler et al., 2014), and from studies that find a restrictive effect only in the case of anticipated depreciation (Agenor, 1991).

Our estimates seems to support a significant link between wholesale prices and both NEER components, starting in 2008 (see Figure 5). As of the beginning of the global financial crisis (autumn 2008), the inflation pass-through for the anticipated and unanticipated decline in the NEER was 0.18 and 0.16 , respectively, or almost the same. However, in the following years, the inflation impact of anticipated NEER depreciation became more significant. As of the end of 2016, the coefficients for inflation pass-through from neer ${ }_{t}$ and neers ${ }_{t}$ increased to 0.32 and 0.25 , respectively. The results generally comply with the quantitative estimates and the conclusion about a greater pass-through effect for substantial depreciations of NEER obtained for consumer prices (Faryna, 2016). However, there is little evidence that minor depreciations have the same effect on prices and that moderate depreciations do not influence prices at all.

The inflationary effect of the domestic component of the money supply is less significant: each percent of $m 2 h_{t}$ growth accelerates wholesale price inflation by $0.1 \mathrm{pp}$. Notably, an increase in FX deposits can produce an anti-inflation effect (that kind of virtuous relationship emerged after 2008). 
Figure 5. Determinants of wholesale price inflation (in first differences)
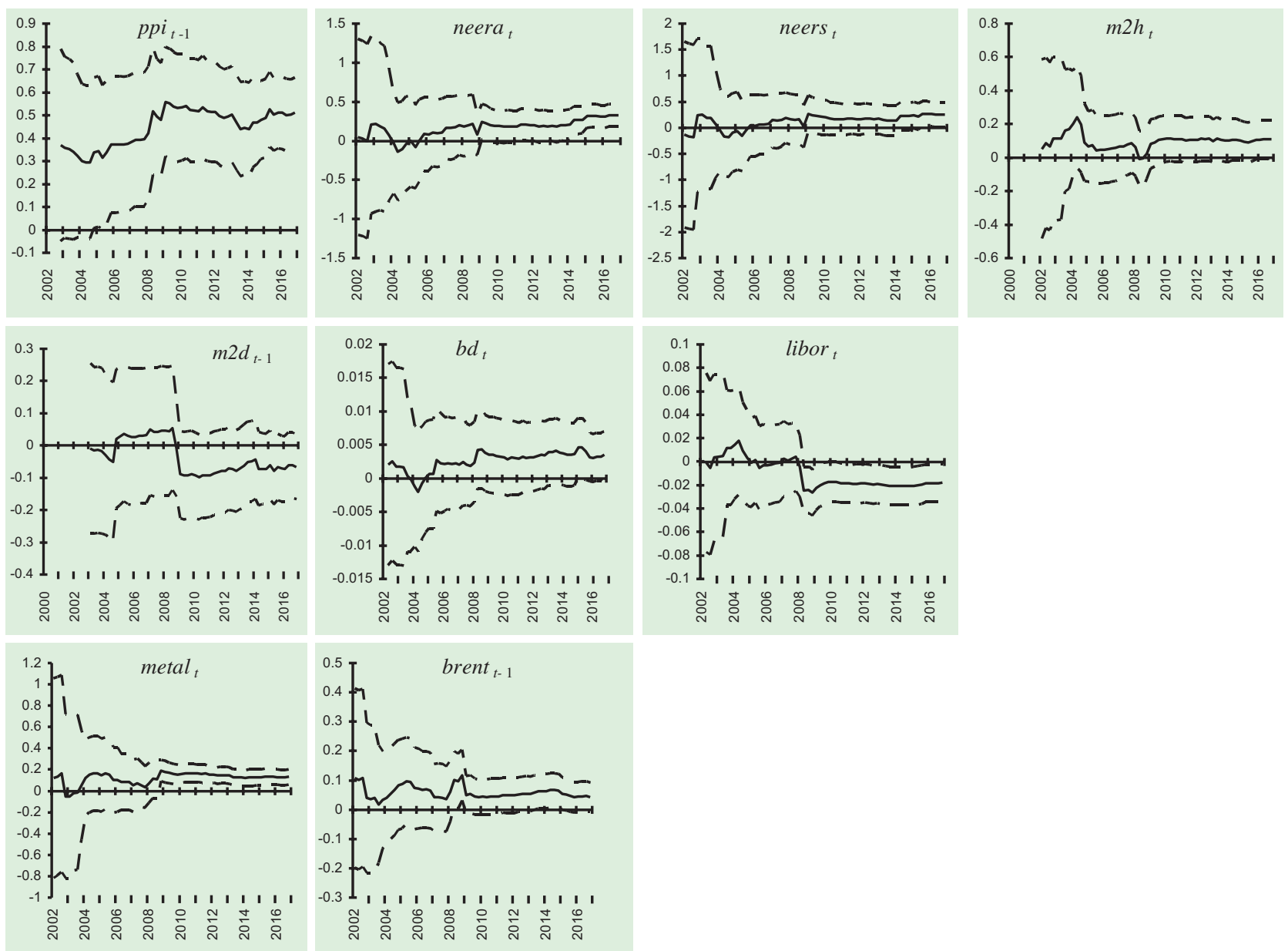

The functional relationships found in this study are in support that FX interventions to strengthen the hryvnia are an efficient measure for a simultaneous non-contradictory decline in inflation combined with output gains, which is relevant for the current economic conditions. Since these FX interventions will most probably limit the domestic money supply, it will provide an additional anti-inflation effect without any output losses. At the same time, any attempts to maintain an undervalued exchange rate of the hryvnia cannot but weaken economic recovery.

In general, the FX crisis of 2008 had a major impact on functional relations for wholesale price inflation. Along with a stronger inflationary pass-through and an emergence of asymmetric effects on the wholesale prices by domestic and FX components of the money supply, the inflationary effects of the budget balance, world metal prices, and world interest rate have strengthened. The inflationary impact of world crude oil prices remained almost unchanged but the respective time-varying coefficients became statistically significant. Finally, the autoregressive inertia with a quarter lag, which had been increasing over the precrisis period, stabilized at the highest level (the respective coefficient grew to 0.52 in 2008 from 0.35 in 2004). During the crisis years of 2014-2015, the wholesale price inertia increased again, but not much.

\section{CONCLUSIONS}

This study's main finding is that Ukraine can expect a clear signal effect (through exchange rate expectations) from FX interventions as an additional tool of the inflation targeting regime. For example, a strengthening of the hryvnia by a reduction in the money supply can bring about a deceleration in inflation without any output losses. This complies with the current realities of a recovery in economic growth with a substantially undervalued hryvnia exchange rate. Owing to the economy's dollarization, both types of currency appreciation - anticipated and unanticipated - can yield a stimulating effect. An increase in the money supply seems to be neutral in respect to GDP in general and industrial and agricultural production in particular. 
Among other findings, the inverse relationship between GDP (industrial production) and the world interest rate is worth of extra attention. Euro area output does stimulate only GDP of Ukraine, with no impact on industrial and agricultural production. At the same time, both indicators - GDP and industrial production - remain dependent on the Russian economy, despite the economic sanctions currently in place. Since volumes of direct trade between Ukraine and Russia have decreased, this means that bilateral trade has been conducted with intermediation of other countries. Contrary to a popular belief, a statistically significant effect of world metal prices on the Ukraine's economy emerged only after 2008.

The specifics of wholesale price inflation in Ukraine lies in the asymmetric dependence on the domestic and FX components of the money supply, which also established in 2008, as well as it is the case for an inflationary effect from improvements in the budget balance. As expected, an increase in the price of crude oil has an inflationary impact. Meanwhile, a similar relationship emerged in 2008 for the world metal prices. Since the financial crisis of 2008-2009 had substantially affected many functional relationships in the Ukraine's economy, statistical methods with time-varying coefficients (the Kalman filter) prove most efficient. If other methods are used, e.g., 2SLS or vector autoregression, the effect of the structural changes driven by the crisis of 2008-2009 should be accounted for.

\section{References}

- Acevedo S., Cebotari A., Greenidge K., Keim G. (2015). External Devaluations: Are Small States Different? Working Paper, No. $15 / 240$, International Monetary Fund, Washington.

- Agenor P.R. (1991). Output, Devaluation and the Real Exchange Rate in Developing Countries. Review of World Economics, Vol. 127 , No. 1, pp. 18-41.

- Ahmed S., Gust C., Kamin S., Huntley J. (2002). Are Depreciations as Contractionary as Devaluations? A Comparison of Selected Emerging and Industrial Economies. FRB International Finance Discussion Paper, No. 737, Federal Reserve System, Washington.

- An L., Kim G., Ren X. (2014). Is devaluation expansionary or contractionary: Evidence based on vector autoregression with sign restrictions. Journal of Asian Economics, Vol. 34, pp. 27-41.

- Bahmani-Oskooee M., Kutan A. (2008). Are devaluations contractionary in emerging economies of Eastern Europe? Economic Change, Vol. 41, No. 1, pp. 61-74.

- Bahmani-Oskooee M., Miteza I. (2006). Are Devaluations Contractionary? Evidence from Panel Cointegration. Economic Issues, Vol. 11, No. 1, pp. 49-64.

- Bebczuk R., Galindo A., Panizza U. (2006). An evaluation of the contractionary devaluation hypothesis. Working Paper, No. 582, Inter-American Development Bank.

- Beirne J., Bijsterbosch M. (2009). Exchange Rate Pass-through in Central and Eastern European Member States, Working Paper Series, No. 1120, European Central Bank.

- Beveridge S., Nelson C. (1981). A New Approach to Decomposition of Economic Time Series into Permanent and Transitory Components with Particular Attention to Measurement of the Business Cycle. Journal of Monetary Economics, Vol. 7, No. 2, pp. 151-174.

- Blanchard O., Faruqee H., Das M. (2010). The Initial Impact of the Crisis on Emerging Market Countries. Brookings Papers on Economic Activity, Vol. 41, No. 1, pp. 263-323.

- Bussière M., Saxena S., Tovar C. (2012). Chronicle of currency collapses: Re-examining the effects on output. Journal of International Money and Finance, Vol. 31, No. 4, pp. 680-708.

- Chou W., Chao C-C. (2001). Are currency devaluations effective? A panel unit root test. Economics Letters, Vol. 72, No. 1, pp. $19-25$.

- Delli Gatti D., Gallegati M., Greenwald B., Stiglitz J. (2007). Net Worth, Exchange Rates, and Monetary Policy: The Effects of a Devaluation in a Financially Fragile Environment. Working Paper, No. 13244, National Bureau of Economic Research.

- Faryna O. (2016). Nonlinear Exchange Rate Pass-Through to Domestic Prices in Ukraine. Visnyk of the National Bank of Ukraine, No. 236, pp. 30-42.

- Fetai B., Zeqiri I. (2010). The impact of monetary policy and exchange rate regime on real GDP and prices in the Republic of Macedonia. Economic and Business Review, Vol. 12, No. 4, pp. 263-284. 
- Forbes K. (2002). Cheap labor meets costly capital: The impact of devaluations on commodity firms. Journal of Development Economics, Vol. 69, No. 2, pp. 335-365.

- Frankel J. (2005). Mundell-Fleming Lecture: Contractionary Currency Crashes in Develo-ping Countries. IMF Staff Papers, No. 52, Vol. 2, pp. 149-192.

- Freund C., Pierola M. (2012). Export Surges: The Power of a Competitive Currency. Working Paper, No. 4750, World Bank Policy Research, Washington, pp. 387-395.

- Grui A., Lepushynskyi V. (2016). Applying Foreign Exchange Interventions as an Additional Instrument Under Inflation Targeting: The Case of Ukraine. Visnyk of the National Bank of Ukraine, No. 238, pp. 39-56.

- Gupta P., Mishra D., Sahay R. (2003). Output Response to Currency Crises. Working Paper, No. 03/230, International Monetary Fund, Washington.

- Haug A., Jędrzejowicz T., Sznajderska A. (2013). Combining monetary and fiscal policy in an SVAR for a small open economy. Working Papers, No. 168, National Bank of Poland, Warsaw.

- Hsing Y. (2016a). Is Real Depreciation Expansionary? The Case of the Slovak Republic. Applied Econometrics and International Development, Vol. 16, No. 2, pp. 55-62.

- Hsing Y. (2016b). Is real depreciation expansionary? The case of the Czech Republic. Theoretical and Applied Economics, Vol. XXIII, No. 3, pp. 93-100.

- Hsing Y. (2016c). Impacts of Government Debt, the Exchange Rate and Other Macroeconomic Variables on Aggregate Output in Croatia. Managing Global Transitions, Vol. 14, No. 3, pp. 223-232.

- Hsing Y., Krenn M. (2016). Effects of fiscal policy and exchange rates on aggregate output in Bulgaria. Socio-Economic Problems and the State, Vol. 14, No. 1, pp. 11-17.

- Hutchison M., Noy I. (2005). How Bad Are Twins? Output Costs of Currency and Banking Crises. Journal of Money, Credit and Banking, Vol. 37, No. 4, pp. 725-752.

- IMF (2006). Exchange Rates and Trade Balance Adjustment in Emerging Market Economies, Washington.

- Kamin S., Klau M. (1998). Some Multi-Country Evidence on the Effects of Real Exchange Rates on Output. International Finance Discussion Papers, No. 611, Board of Governors of the Federal Reserve System, Washington.

- Kamin S., Rogers G. (2000). Output and the RER in developing countries: an application to Mexico. Journal of Development Economics, Vol. 61, No. 1, pp. 85-109.

- Kandil M. (2015). The Adverse Effects of Real Exchange Rate Variability in Latin America and the Caribbean. Journal of Applied Economics, Vol. XVIII, No. 1, pp. 99-120.

- Kandil M., Mirzaie I. (2003). The Effect of Exchange Rate Fluctuations on Output and Prices: Evidence from Developing Countries. Working Paper, No. 03/200, International Monetary Fund, Washington.

- Kohler M., Manalo J., Perera D. (2014). Exchange Rate Movements and Economic Activity. Bulletin Reserve Bank of Australia, pp. 47-54.

- Krugman P., Taylor R. (1978). Contractionary effects of devaluation. Journal of International Economics, Vol. 78, No. 8, pp. 445-456.

- Lizondo J., Montiel P. (1988). Contractionary Devaluation in Developing Countries: An Analytical Overview. Working Paper, No. 88/51, International Monetary Fund, Washington.

- McCallum B. (1996). International Monetary Economics. N.Y.: Oxford: Oxford University Press.

- Mendoza E., Uribe M. (2000). Devaluation risk and the business-cycle implications of exchange-rate management. CarnegieRochester Conference Series on Public Policy, Vol. 53, pp. 239-296.

- Mills T., Pentecost E. (2001). The real exchange rate and the output response in four EU accession countries. Emerging Markets Review, Vol. 2, pp. 418-430.

- Mirdala R. (2013). Real Output and Prices Adjustments Under Different Exchange Rate Regimes. William Davidson Institute Working Paper, No. 1064, The University of Michigan. 
- Miteza I. (2006). Devaluation and output in five transition economies: A panel cointegration approach of Poland, Hungary, Czech Republic, Slovakia and Romania, 1993-2000. Applied Econometrics and International Development, Vol. 6, No. 1, pp. 77-86.

- Moreno R. (1999). Depreciation and Recessions in East Asia. FRBSF Economic Review, Vol. 3, pp. 27-40.

- Morley J. (2011). The Two Interpretations of the Beveridge-Nelson Decomposition. Macroeconomic Dynamics, Vol. 15, No. 3, pp. 419-439.

- Pineres S., Cantavella-Jorda M. (2010). Short-run effects of devaluation: a disaggregated analysis of Latin American exports. Applied Economics, Vol. 42, pp. 133-142.

- Rojas-Suarez L. (1992). Limited Capital Markets And The Real Effects Of Monetary Stabilization Policies Under Alternative Exchange Rate Regimes. Journal of International Money and Finance, Vol. 11, No. 6, pp. 594-613.

- Sanchez M. (2005). The Link Between Interest Rates and Exchange Rates. Do Contractionary Depreciations Make a Difference? Working Paper Series, No. 548, European Central Bank, Frankfurt.

- Shevchuk V. (2008). Platizhnyj balans, ekonomichne zrostannya i stabilizacijna polityka. Lviv: Kalvaria.

- Shevchuk V. (2016a). Modelling of Exchange Rate Effects and Complimentaries Between Agriculture and Industry in Ukraine. Information Systems in Management, Vol. 5, No. 3, pp. 401-412.

- Shevchuk V. (2016b). The Real and Nominal Effects of Large Devaluations in Ukraine. Argumenta Oeconomica Cracoviensia, Vol. 14, pp. 97-118.

- Stelmakh V. (2001). National Bank of Ukraine: first ten years of activity. Visnyk of the National Bank of Ukraine, No. 4, pp. 2-4.

- Twarowska K. (2015). The Impact of Exchange Rate on Poland's Trade Flows. International Journal of Management, Knowledge and Learning, Vol. 4, No. 1, pp. 41-57.

- Yurchyshyn V. (2016).Globalnyj kontekst valutnoi polityky I napryamy posylennya stijkoski natsionalnoyi hroshovoji odynytsi v Ukraini. Suchasna valutna polityka ta osoblyvosti jiji realizatsii v Ukraini. Kyiv: Zapovit, s. 5-47. 